www.nature.com/ja

\title{
Citric acid inhibits a bacterial ceramidase and alleviates atopic dermatitis in an animal model
}

\author{
Hiroyuki Inoue, Tetsuya Someno, Manabu Kawada and Daishiro Ikeda \\ The Journal of Antibiotics (2010) 63, 611-613; doi:10.1038/ja.2010.91; published online 21 July 2010
}

Keywords: atopic dermatitis; ceramidase; citric acid; inhibitor; treatment

Ceramide constructs a multi-lamellae structure in the stratum corneum in the skin and functions as a permeability barrier as well as a water retainer. ${ }^{1}$ Unfortunately, the content of ceramide is often found to be decreased in lesions of atopic skin. ${ }^{2}$ The reduction of ceramide consequently induces dry skin of patients with atopic dermatitis and compromises the permeability barrier permitting the invasion of allergens or irritants. ${ }^{3}$ Interestingly, such atopic skin is frequently colonized by ceramidase-producing bacteria such as Pseudomonas aeruginosa. ${ }^{4}$ Ceramidase is an enzyme that catalyzes the hydrolysis of the $\mathrm{N}$-acyl linkage of ceramide to produce a free fatty acid and a sphingosine base. Okino et al. have isolated a ceramidase-producing bacterium, $P$. aeruginosa AN17, from the skin of patients with atopic dermatitis ${ }^{5}$ and cloned the gene encoding its ceramidase. $^{6}$

These reports lead to the hypothesis that the ceramidase from colonizing bacteria contributes to the reduction of ceramide in atopic skin lesions and that inhibiting the bacterial ceramidase will prevent the ceramide decrease in atopic skin and improve the disease. We therefore searched for ceramide inhibitors among natural resources such as microbial cultured broths of actinomyces and fungi. As a result, we recently discovered ceramidastin, a novel inhibitor of bacterial ceramidase, from the culture broth of Penicillium sp. Mer-f17067. ${ }^{7}$ Further, our screening program has resulted in the finding that citric acid is another potent inhibitor of the bacterial ceramidase. Here we report the activity of citric acid against the bacterial ceramidase and atopic dermatitis animal models.

In the course of our screening program for ceramidase inhibitors, we found one of the fungus-cultured broths showed the inhibitory activity against ceramidase of $P$. aeruginosa. We purified the active material and identified it as citric acid by physicochemical and structural analyses. Citric acid was detected as a pink spot by anisaldehyde/sulfuric acid dyeing on a silica gel TLC plate developed in $70 \%$ ethanol $\left(R_{\mathrm{F}}=0.42\right)$. Citric acid also showed specific mass spectra $m / z$ at $191[\mathrm{M}-\mathrm{H}]^{-}, 213[\mathrm{M}+\mathrm{Na}-\mathrm{H}]^{-}$and $235[\mathrm{M}+2 \mathrm{Na}-\mathrm{H}]^{-}$ by ESI MS. We then purchased commercially available citric acid and confirmed its activity against the bacterial ceramidase compared with the purified one. Ceramidase activity was assessed according to the method by Okino et al. ${ }^{5}$ with minor modifications as described. ${ }^{7}$ As shown in Figure 1a, citric acid was found to inhibit the Pseudomonas ceramidase with an $\mathrm{IC}_{50}$ value of $19.6 \mu \mathrm{g} \mathrm{ml}^{-1}$ as well as the purified one. Although the inhibitory activity of the purified citric acid was somewhat weak, it is considered that the effects would be altered by its purity or salt condition. We therefore used the purchased citric acid for the further experiments. In contrast, citric acid did not inhibit human ceramidase even at $200 \mu \mathrm{g} \mathrm{ml}^{-1}$ (Figure 1a). For the assay of human ceramidase, human prostate cancer DU-145 cells overexpressing human ceramidase were lysed in $10 \mathrm{~mm}$ phosphate buffer $(\mathrm{pH}$ 7.0), $0.25 \mathrm{M}$ sucrose and $1 \mathrm{~mm}$ EDTA. The cell lysates were used as a source of human ceramidase. Furthermore, citric acid did not show antibacterial activity against $P$. aeruginosa even at $1000 \mu \mathrm{g} \mathrm{ml}^{-1}$ (Figure 1b). Although we examined the effects of other organic acids having a carboxy group on the Pseudomonas ceramidase, we found that other such organic acids failed to effectively inhibit the ceramidase more than $50 \%$ of control even at $200 \mu \mathrm{g} \mathrm{ml}^{-1}$ (Figure 2).

We next examined the effect of citric acid on atopic dermatitis model NC/Nga mice. ${ }^{8,9}$ It is reported that mast cells are increased in the dermis with dermatitis and that tacrolimus hydrate improves the spontaneous dermatitis in NC/Nga mice. ${ }^{8}$ Furthermore, we have recently reported that ceramidastin efficiently reduces the mast cells in the mouse model. ${ }^{7}$ As shown in Figure 3, the application of the Pseudomonas ceramidase on the back of mice resulted in the significant increase in mast cells in the dermis. However, citric acid treatment significantly inhibited the increase in mast cells in the dermis (Figure 3).

By our screening program, we found that citric acid is a potent inhibitor of the Pseudomonas ceramidase. Although we examined the effects of other organic acids having a carboxy group, we could not find another inhibitor. Among them isocitric acid was an analog of citric acid, but it did not show the inhibitory activity against the ceramidase. Therefore, it is suggested that the inhibitory activity of citric acid strictly attributes to its structure. Because we have used all acids as sodium salts and the buffered solution for the assay of the 

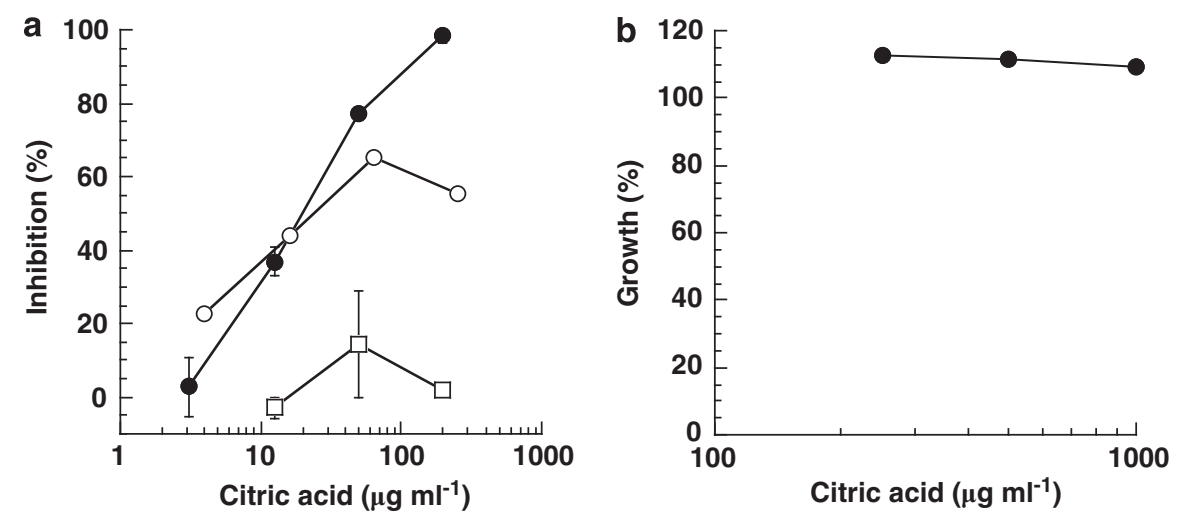

Figure 1 Effect of citric acid on Pseudomonas ceramidase. (a) Pseudomonas ceramidase activity (circles) and human ceramidase activity (squares) were determined by the method as described in text. Values are means of quadruplicate determinations \pm s.d. Closed circles, purchased citric acid; open circles, purified citric acid. (b) Effect of citric acid on the growth of Pseudomonas aeruginosa was determined by $24 \mathrm{~h}$ culture. Values are means of duplicate determinations. Each s.e. is $<10 \%$.
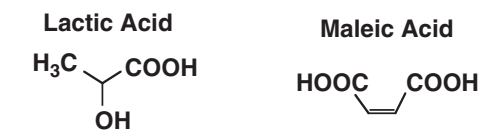

Acetic Acid

$\mathrm{CH}_{3}-\mathrm{COOH}$

Fumaric Acid<smiles>O=C(O)CC(O)CC(=O)O</smiles>

$\mathrm{OH}$<smiles>O=C(O)C=CC(=O)O</smiles>

Succinic Acid<smiles>O=C(O)CCC(=O)O</smiles><smiles>O=C(O)C(O)C(=O)O</smiles><smiles>O=C(O)C(O)C(=O)O</smiles>

Adipic Acid<smiles>O=CCCCCC(=O)O</smiles>

Phtalic Acid

$\mathrm{COOH}$

$\mathrm{COOH}$

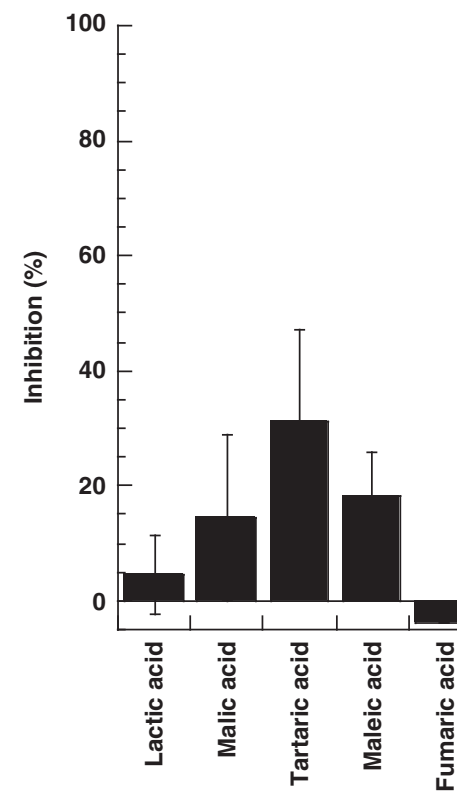

\section{$\left(200 \mu \mathrm{g} \mathrm{ml}^{-1}\right)$}

Figure 2 Effects of various organic acids on Pseudomonas ceramidase. Inhibitory activities of various organic acids against Pseudomonas ceramidase were determined as described. Values are means of quadruplicate determinations \pm s.d. 
a
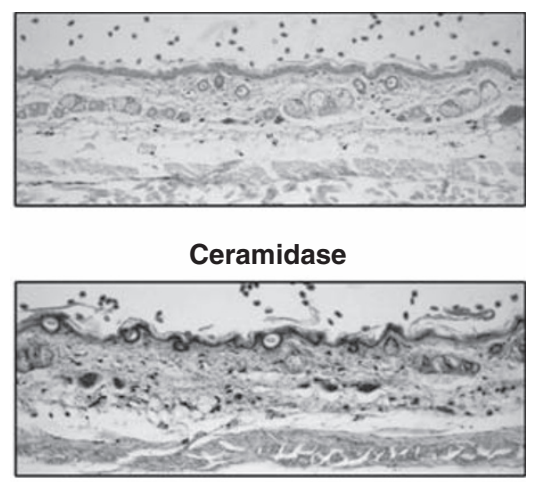

Ceramidase+citric acid

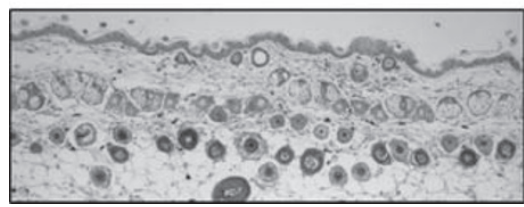

b

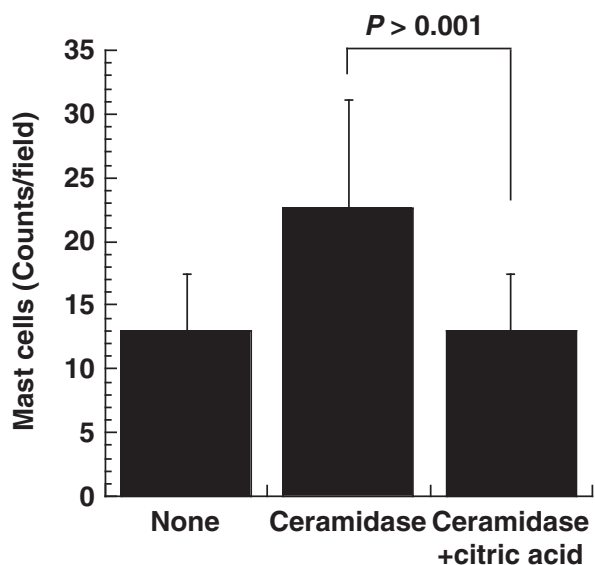

Figure 3 Effect of citric acid on NC/Nga mice skin. NC/Nga mice (six mice per group) were treated with Pseudomonas ceramidase on the back skin with or without citric acid at $1 \mathrm{mg} \mathrm{ml}^{-1}$. Mast cells in the dermis were stained by toluidine blue and counted. (a) Representative photos of the dermis sections stained by toluidine blue. (b) Mast cell counts in the dermis. The values were mean \pm s.d. of six mice.

ceramidase, we can rule out the possibility that acidity of the tested compounds inhibit the ceramidase.

We have recently reported that ceramidastin, a novel compound, inhibits ceramidase activity of Pseudomonas culture with an $\mathrm{IC}_{50}$ of $6.25 \mu \mathrm{g} \mathrm{ml}^{-1}$. Compared with ceramidastin, the inhibitory activity of citric acid is slightly weak, but citric acid is widely used as one of ingredients of bath salts, in which some are even advertised to improve dermatitis. Thus, one of advantages for use of citric acid might be explained by this study. When we examined the effect of citric acid on the atopic dermatitis model, we found that citric acid suppressed the inflammation induced by the application of the Pseudomonas ceramidase. Therefore, it is suggested that citric acid would improve atopic dermatitis exacerbated by the infection of bacteria in the skin.

\section{ACKNOWLEDGEMENTS}

We thank Meiji Seika Kaisha for fermentation broths of fungal strains. We also thank Dr H Kumagai for helpful discussion.
1 Elias, P. M. \& Menon, G. K. Structural and lipid biochemicla correlates of the epidermal permeability barrier. Adv. Lipd. Res. 24, 1-26 (1991).

2 Imokawa, G. et al. Decereased level of ceramides in stratum corneium of atopic dermatitis: an etiologic factor in atopic dry skin? J. Invest. Dermatol. 96, 523-526 (1991).

3 Bos, J. D., Kapsenberg, M. L. \& Smitt, J. H. Pathogenesis of atopic eczema. Lancet 343, 1338-1341 (1994).

4 Ohnishi, Y., Okino, N., Ito, M. \& Imayama, S. Ceramidae activity in bacterial skin flora as a possible cause of ceramide deficiency in atopic dermatitis. Clin. Diagn. Lab. Immunol. 6, 101-104 (1999).

5 Okino, N., Tani, M., Imayama, S. \& Ito, M. Purification and characterization of a nove ceramidase from Pseudomonas aeruginosa. J. Biol. Chem. 273, 14368-14373 (1998).

6 Okino, N. et al. Molecular cloning, sequencing, and expression of the gene encoding alkaline ceramdase from Pseudomonas aeruginosa: cloning of a ceramidase homologue from Mycobacterium tuberculosis. J. Biol. Chem. 274, 36616-36622 (1999).

7 Inoue, H. et al. Ceramidastin, a novel bacterial ceramidase inhibitor, produced by Penicillium sp. Mer-f17067. J. Antibiot. 62, 63-67 (2009).

8 Hiroi, J. et al. Effect of tacrolimus hydrate (FK506) ointment on spontaneous dermatitis in NC/Nga mice. Jpn J. Pharmacol. 76, 175-183 (1998).

9 Aioi, A. et al. Impairment of skin barrier function in NC/Nga Tnd mice as a possible model for atopic dematitis. Br. J. Dermatol. 144, 12-18 (2001). 